Jurnal Kesehatan

Volume 11, Nomor 1, Tahun 2020

ISSN 2086-7751 (Print), ISSN 2548-5695 (Online) http://ejurnal.poltekkes-tjk.ac.id/index.php/JK

\title{
Peran Fatwa Muhammadiyah tentang Hukum Merokok dalam Sikap, Norma Subjektif, dan Kontrol Perilaku terhadap Perilaku Merokok
}

\section{The Role of Fatwa Muhammadiyah on Smoking Law in Attitude, Subjective Norm, and Behavior Control toward Smoking Behavior}

\author{
Muh Nur Akhsin Ridho ${ }^{1}$, Evi Martha ${ }^{2}$ \\ Fakultas Kesehatan Masyarakat, Universitas Indonesia, Indonesia
}

\section{ARTICLE INFO}

\section{Article history:}

Received date

06 Mar 2020

Revised date

17 May 2020

Accepted date

25 May 2020

Keywords:

Fatwa;

Muhammadiyah;

Smoking behavior.

Kata kunci:

Fatwa;

Muhammadiyah;

Perilaku merokok.

\author{
ABSTRACT/ ABSTRAK
}

Muhammadiyah has issued a fatwa that smoking is haram. Nevertheless, there are still muhammadiyah residents who remain to smoke. This thesis discusses the role of fatwa Muhammadiyah about haram smoking law against employee smoking behavior. The purpose of this research was to know the role of Muhammadiyah fatwa about smoking law in attitude, subjective norm, behavior control, and intention toward smoking behavior of employees of Da'wah Muhammadiyah Center. This research was qualitative and choosing a location at the Muhammadiyah Da'wah Center Jakarta. The number of informants was 14 people. Informants were obtained by purposive and data collection techniques through observation, document review, and in-depth interviews. The results showed that for smokers informants, attitudes and subjective norms did not contribute to smoking cessation behavior, while behavior controls play a role in smoking cessation behavior. For non-smoking informants, attitudes, subjective norms, and behavioral controls play a role in non-smoking behaviors. Similarly for ex-smoker informants, attitudes, subjective norms, and behavioral controls play a role in committed non-smoking behaviors. It was suggested to the Muhammadiyah Central Executive to improve the fatwa status of smoking law into Muhammadiyah's decision to be more binding organizationally and for Muhammadiyah Da'wah Center to be a role model of implementation fatwa smoking law in Muhammadiyah.
Muhammadiyah telah mengeluarkan fatwa bahwa merokok adalah haram. Namun demikian, masih terdapat warga Muhammadiyah yang tetap merokok. Tesis ini membahas peran fatwa Muhammadiyah tentang hukum haram merokok terhadap perilaku merokok pegawai. Tujuan penelitian adalah untuk mengetahui peranan fatwa Muhammadiyah tentang hukum merokok dalam sikap, norma subjektif, kontrol perilaku, dan niat terhadap perilaku merokok pegawai Pusat Dakwah Muhammadiyah. Penelitian ini adalah penelitian kualitatif dan memilih lokasi di Pusat Dakwah Muhammadiyah Jakarta. Jumlah informan sebanyak 14 orang, Informan diperoleh secara purposive dan teknik pengumpulan datanya melalui observasi, telaah dokumen, dan wawancara mendalam. Hasil penelitian menunjukkan bahwa bagi informan perokok, sikap dan norma subjektif tidak berperan terhadap perilaku berhenti merokok, sementara kontrol perilaku berperan terhadap perilaku berhenti merokok. Bagi informan yang tidak merokok, sikap, norma subjektif, dan kontrol perilaku berperan terhadap perilaku tidak merokok. Demikian juga bagi informan mantan perokok, sikap, norma subjektif, dan kontrol perilaku berperan terhadap perilaku berkomitmen tidak merokok. Disarankan kepada Pimpinan Pusat Muhammadiyah agar meningkatkan status fatwa hukum merokok menjadi keputusan Muhammadiyah supaya lebih mengikat secara organisasi dan bagi Pusat Dakwah Muhammadiyah agar dapat menjadi role model implementasi fatwa hukum merokok di lingkungan Muhammadiyah.

\section{Corresponding Author:}

Evi Martha

Fakultas Kesehatan Masyarakat, Universitas Indonesia, Indonesia

Email: evie.martha@ui.ac.id 


\section{PENDAHULUAN}

Berdasarkan The Tobacco Control Atlas ASEAN Region Third Edition bahwa persentase penduduk dunia (WHO Region) yang mengonsumsi tembakau secara berurutan adalah penduduk Cina sebanyak 31,5\%, penduduk Eropa sebanyak 21\%, penduduk Amerika sebanyak $11,3 \%$, penduduk Asia Tenggara sebanyak $10,8 \%$, penduduk Pasifik Barat (tidak termasuk Cina) sebanyak $9,4 \%$, penduduk Mediterania Timur sebanyak $7 \%$, dan pada penduduk Afrika sebanyak 3\% (Lian, 2016). Sedangkan data negara perokok terbesar di dunia adalah Cina, Rusia, Amerika Serikat, dan Indonesia. Indonesia merupakan Negara keempat dengan perokok terbesar tersebut (Eriksen, et al., 2015). Selanjutnya, jika dilihat dari persentase perokok di negara-negara Association of Southeast Asian Nations (ASEAN), maka perokok di Indonesia sebanyak 53,3\%, Filipina 13,5\%, Vietnam $12,7 \%$, Myanmar 5,1\%, Thailand 8,9\%, Malaysia 4,07\%, Kamboja1,4\%, Laos 0,67\%, Singapura 0,3\%, dan Brunei 0,06\% (Lian, 2016).

World Bank menyatakan angka kematian perokok di dunia diperkirakan akan mencapai 10 juta jiwa dan $70 \%$ diantaranya berasal dari Negara berkembang pada tahun 2030. Saatini, $50 \%$ kematian akibat rokok berada di Negara berkembang. Bila kecenderungan ini terus berlangsung, sekitar 650 juta orang akan kehilangan nyawa disebabkan oleh rokok, yang setengahnya berusia produktif dan akan kehilangan umur hidup (lost life) sebesar 20 sampai 25 tahun (Kementerian Kesehatan, 2016).

Kebiasaan merokok sangatlah banyak ditemukan di Indonesia, baik oleh perokok dewasa maupun remaja. Hal tersebut menjadi suatu kebiasaan dan perokok sulit menghentikannya dikarenakan rokok mengandung zat-zat yang bersifat adiktif (candu), sehingga semakin hari semakin banyak jumlah rokok yang dihisap. Berdasarkan data Survei Sosial Ekonomi Nasional Modul Kesehatan dan Perumahan (Susenas MKP) 2013, persentase jumlah perokok di Indonesia sebesar 28,3\%. Dari persentase tersebut, jumlah perokok umur 10-19 tahun sebanyak 5,24\%, umur 20-29 tahun sebanyak 23,63\%, dan umur 30-60 tahun ke atas sebanyak 71,13\% (Badan Pusat Statistik, 2015).

Rokok adalah "salah satu produk tembakau yang dimaksudkan untuk dibakar dan dihisap dan/atau dihirup asapnya, termasuk rokok kretek, rokok putih, cerutu atau bentuk lainnya yang dihasilkan dari tanaman nicotiana tabacum, nicotiana rustica, dan spesies lainnya atau sintetisnya yang asapnya mengandung nikotin dan tar, dengan atau tanpa bahan tambahan" (Peraturan Pemerintah Republik Indonesia No. 109 Tahun 2012, 2012). Rokok mengandung 4000 zat kimia berbahaya seperti nikotin yang bersifat adiktif dan tar yang bersifat karsinogenik, bahkan juga formalin yang berbahaya bagi kesehatan. Beberapa penyakit yang ditimbulkan karena kebiasaan merokok adalah seperti emfisema, kanker paru, bronkitis kronis, penyakit jantung koroner, peningkatan kolesterol darah, Berat Bayi Lahir Rendah (BBLR) pada bayi ibu perokok, keguguran, bayi lahir mati, dan masih ada penyakit-penyakit lainnya (Kementerian Kesehatan, 2011).

Berdasarkan Sensus Penduduk 2010 oleh Badan Pusat Statistik (2010), jumlah penduduk Indonesia yang beragama Islam adalah sebanyak 207.176.162 (87,2\%) jiwa dari 237.641.326 jiwa total penduduk (Penduduk laki-laki sebanyak 119.630.913 jiwa dan perempuan sebanyak 118.010.413 jiwa). Setelah itu secara berurutan yang beragama Kristen sebanyak 16.528.513 $(6,96 \%)$, Katolik 6.907 .873 (2,91\%), Hindu 4.012.116 (1,69\%), Budha 1.703.254 (0,72), Khong $\mathrm{Hu} \mathrm{Chu} 117.091$ (0,05\%), dan agama lainnya $299.617(0,13 \%)$. Jumlah penduduk saat ini menurut World Population Data Sheet 2017, terdapat sebanyak 264 juta penduduk (Population Reference Bureau, 2017) dan merupakan negara yang mayoritas beragama Islam. Hal tersebut berarti dapat diperkirakan bahwa banyak diantara perokok adalah mereka yang beragama Islam. Agama Islam di Indonesia memiliki beberapa organisasi keagamaan Islam seperti Nahdlatul Ulama, Muhammadiyah, Persatuan Islam, Al Washliyah, Majelis Ulama Indonesia (MUI), dan organisasi lainnya. Nahdlatul Ulama adalah organisasi yang terbesar dan disusul oleh Muhammadiyah.

Islam sangat menjunjung tinggi terhadap pemeliharaan jiwa. Menurut Imam Syathibi, Allah S.W.T menurunkan syariat (aturan hukum) adalah untuk kemaslahatan dan menolak kemadaratan (jalbu al-mașāitih wa dar'u almafāsid). Maslahat ini dibagi menjadi tiga bagian penting yaitu daruriyyāt (primer), hajiyyāt (sekunder), dan tahsinat (tersier, lux). Maqāşsid atau Maşlahah Daruriyyah adalah sesuatu yang harus ada untuk terwujudnya kemaslahatan agama dan dunia. Jika hal tersebut tidak ada, maka akan menimbulkan kerusakan bahkan hilangnya hidup dan kehidupan. Mașlahah Daruriyyah ini ada lima yaitu: memelihara agama (al-dĩn), jiwa (al-nafs), keturunan (alnasl), harta (al-māl), dan akal (al-'aql) (Kasdi, 2014). 
Memelihara jiwa merupakan bagian yang penting untuk diwujudkan. Memelihara jiwa dalam agama Islam secara bersamaan menuntut pada pemeliharaan raga diantaranya adalah pemeliharaan kesehatan seperti tidak merokok. Menurut banyak penelitian bahwa merokok sangat berbahaya bagi kesehatan. Sebuah penelitian menyatakan bahwa kandungan kimia dalam tembakau jumlahnya mencapai 2.500 komponen, sedangkan dalam asap pembakaran rokok terdapat 4.800 macam komponen (Tirtosastro \& Murdiyati, 2010).

Berdasarkan masalah rokok tersebut, para ulama dan organisasi/lembaga merasa terpanggil untuk menentukan hukum dari rokok itu sendiri. Membiarkan permasalahan dan kebingungan umat tidak dapat dibenarkan, oleh karenanya fatwa harus segera diberikan oleh para ulama untuk menghilangkan ketidak pastian ajaran Islam berkenaan dengan permasalahan yang dihadapi (Syuhadak, 2013).

Berkaitan dengan hukum merokok, diantara organisasi keagamaan Islam di Indonesia terdapat pandangan yang berbeda-beda. Nahdlatul Ulama lebih berpendapat bahwa hukum merokok adalah makruh (Abdullah, 2013), Muhammadiyah berpendapat bahwa hukum merokok adalah haram (Muhammadiyah, 2010), dan Majelis Ulama Indonesia (MUI) juga berbeda pendapat tentang hukum merokok ini. Namun setidaknya MUI bersepakat bahwa haram hukumnya merokok di tempat umum, bagi anakanak, dan bagi ibu hamil (Trigiyatno, 2011). Keberadaan sebuah fatwa seharusnya menjadi suatu hal yang sangat penting dan dapat berpengaruh terhadap perilaku seorang muslim termasuk perilaku merokok. Oleh karena itu, penelitian ini dilakukan bertujuan untuk mengetahui peranan fatwa haram merokok yang dikeluarkan oleh Majelis Tarjih dan Tajdid Pimpinan Pusat Muhammadiyah terhadap perilaku merokok pegawai Pusat Dakwah Muhammadiyah.

\section{METODE}

Desain penelitian yang digunakan dalam penelitian ini adalah penelitian kualitatif dengan melakukan pendekatan studi kasus. Penelitian dilakukan selama 2 bulan yaitu bulan Mei sampai dengan Juni 2018. Pengambilan informan secara purposive sampling kepada pegawai Pusat Dakwah Muhammadiyah Jakarta yang terdiri dari pegawai Pimpinan Pusat Muhammadiyah, Pegawai Lembaga Zakat, Infaq, Shadaqah Muhammadiyah (LAZISMU), pegawai TV
Muhammadiyah (TV MU), Security, dan Office Boy. Adapun cara peneliti mendapatkan informan tersebut yaitu terlebih dahulu peneliti menemui kepala Pusat Dakwah Muhammadiyah Jakarta dan menanyakan langsung data pegawai beserta identitasnya, setelah data tersebut didapatkan kemudian peneliti mensinkronkan dengan kriteria inklusi penelitian, jika data informan yang diperoleh sesuai dengan kriteria inklusi maka informan tersebut akan dijadikan sebagai informan/partisipan dalam penelitian ini.

Informan adalah Pegawai Pusat Dakwah Muhammadiyah Jakarta sebanyak 14 yang terdiri dari 4 orang pegawai yang tidak merokok, 5 orang pegawai yang merokok, 2 orang pegawai mantan perokok serta 3 orang sebagai key informan yang bersedia menjadi informan. Sedangkan pegawai perempuan dan pegawai yang tidak mengetahui tentang fatwa Majelis Tarjih dan Tajdid Muhammadiyah tentang hukum merokok di Pusat Dakwah Muhammadiyah tidak menjadi informan dalam penelitian ini.

Penelitian menggunakan teknik wawancara mendalam, telaah dokumen, observasi (pengamatan), sebagai cara untuk mengumpulkan data yang diperlukan dalam penelitian. Penelitian dilakukan setelah terlebih dahulu mendapat rekomendasi dari Tim Kaji Etik Fakultas Kesehatan Masyarakat Universitas Indonesia (FKMUI) dan dinyatakan layak untuk dilaksanakan dengan surat keterangan nomor: 429/UN2.F10/PPM.00.02/2018 tanggal 15 Mei 2018 serta telah mendapatkan izin turun lapangan dari pihak informan. Selanjutnya untuk memenuhi kode etik penelitian maka yang terpenting sebelum dilaksanakan wawancara mendalam dan observasi partisipasi pasif untuk mendapatkan data primer adalah menyiapkan informed consent. Sedangkan analisis yang digunakan dalam penelitian ini adalah analisis isi atau konten.

\section{HASIL}

Karakteristik Informan yang merokok terdiri dari lima orang yang berasal dari PP. Muhammadiyah, Lazismu, TV MU, Security, dan Office Boy. Usia informan perokok bervariasi, paling muda berusia 26 tahun dan paling tua adalah 54 tahun. Usia mulai merokok paling muda pada saat 13 tahun dan paling tua usia 17 tahun. Sedangkan karakteristik Informan yang tidak merokok terdiri dari empat orang yang berasal dari PP. Muhammadiyah, TV MU, Security, dan Office Boy. Usia informan tidak 
merokok bervariasi, paling muda berusia 28 tahun dan paling tua adalah 54 tahun.

Karakteristik Informan mantan perokok terdiri dari dua orang yang berasal dari PP. Muhammadiyah dan TV MU. Usia informan mantan perokok hampir sama yaitu masingmasing 39 tahun dan 41 tahun. Usia mulai merokok keduanya adalah sejak memasuki sekolah tingkat SMA. Mereka berhenti merokok pada tahun 2010 dan 2013. Sedangkan karakteristik Key Informan terdiri dari tiga orang yang berasal dari PP. Muhammadiyah, TV MU, dan anggota Majelis Tarjih dan Tajdid Pimpinan Pusat Muhammadiyah. Usia key informan hampir sama yaitu 54 tahun dan 56 tahun. Seluruh key informan merupakan unsur pimpinan di lingkungan Muhammadiyah yang semuanya tidak merokok.

\section{Peranan Fatwa Terhadap Hukum Merokok}

Muhammadiyah memandang bahwa konsumsi rokok di Indonesia sudah pada tahapan yang mencemaskan. Dampak negatif dari konsumsi rokok, tidak hanya merugikan kesehatan perokok dan orang lain yang terpapar asap rokok, tetapi dapat juga merusak perekonomian keluarga terutama oleh masyarakat miskin.Pemaparan dalam Halaqah Tarjih tentang Fikih Pengendalian Tembakau yang dilaksanakan pada hari Ahad 21 Rabiul Awal $1431 \mathrm{H}$ yang bertepatan dengan tanggal 7 Maret $2010 \mathrm{M}$, memaparkan bahwa Indonesia belum meratifikasi Framework Convention on Tobacco Control $(F C T C)$. Selain itu, disampaikan juga bahwa cukai tembakau di Indonesia masih rendah dibandingkan dengan beberapa negara lain sehingga harga rokok di Indonesia sangat murah.

Menanggapi fakta-fakta mengenai tren konsumsi rokok yang semakin miris dari tahun ke tahun dan melihat dampak yang diakibatkan dari merokok, pada Tahun 2010, Muhammadiyah melalui Majelis Tarjih dan Tajdid Pimpinan Pusat Muhammadiyah mengeluarkan fatwa Nomor 6/SM/MTT/III/2010 tanggal 22 Rabiul Awal 1431 H/8 Maret 2010 tentang Hukum Merokok yang menyatakan bahwa merokok merugikan kesehatan dan haram hukumnya. Hal tersebut sebagai peninjauan kembali dari fatwa sebelumnya yaitu fatwa Majelis Tarjih dan Tajdid Pimpinan Pusat Muhammadiyah yang diterbitkan tahun 2005 dan tahun 2007 tentang Hukum Merokok.Sebagai tindak lanjut dari Fatwa Majelis Tarjih dan Tajdid Pimpinan Pusat Muhammadiyah Tahun 2010 tersebut, telah dikeluarkan peraturan turunan fatwa seperti Pernyataan Kesepakatan Bersama tentang
Penerapan Kawasan Tanpa Rokok oleh 4 (empat) Majelis, adanya surat edaran nomor 412/I.0/H/2011 perihal penerapan Kawasan Tanpa Rokok (KTR) di Lingkungan Muhammadiyah, dan adanya buku pedoman penerapan KTR di Lingkungan Muhammadiyah.

Muhammadiyah sangat konsen dengan upaya pengendalian rokok dan menguatkannya melalui penerbitan fatwa tentang hukum merokok dalam rangka untuk berpartisipasi pada upaya pembangunan kesehatan masyarakat secara maksimal. Muhammadiyah juga ikut dalam menciptakan lingkungan hidup sehat yang merupakan hak setiap orang. Dalam pelaksanaan fatwa tersebut, Muhammadiyah telah membuat Kerangka Kerja Muhammadiyah dalam Pengendalian Produk Tembakau pada tahun 2014 melalui surat keputusan bersama. Di dalam surat tersebut diantaranya berisi tentang proteksi dari dampak produk tembakau, larangan iklan, promosi dan sponsorship, serta pelarangan penjualan produk tembakau.

\section{Sikap Terhadap Fatwa}

Berdasarkan informasi dari para informan, baik perokok, tidak perokok, dan mantan perokok bahwahampir semua sikap dari mereka terhadap perilaku merokok adalah sesuatu yang tidak baik. Salah satu tanggapan mereka yang merokok tentang perilaku merokok, menyatakan bahwa perilaku merokok yang dilakukan di kantor atau di tempat umum adalah perilaku yang sangat tidak baik. Sementara salah satu tanggapan dari informan yang tidak merokok, mengatakan bahwa perilaku merokok adalah hak setiap orang akan tetapi seharusnya ketika merokok, seorang perokok harus melihat kepentingan publik.Demikian juga pendapat oleh seorang mantan perokok. Ia mengatakan bahwa merokok adalah hak seseorang. Namun, sebagai seorang yang pernah merokok, ia mengatakan bahwa seorang perokok seharusnya merokok di tempattempat yang telah disediakan.Sebagai salah satu alasan dari tanggapan tersebut, bahwa perilaku merokok dapat mempengaruhi psikologi seseorang, perempuan yang didekatnya dapat terganggu, dan secara umum dapat menimbulkan ketidaknyamanan bagi orang di sekitarnya yang tidak merokok.

Hal yang serupa juga disampaikan oleh key informan, bahwa terdapat tingkatan pada diri seorang perokok. Terdapat perokok ringan, perokok sedang, dan perokok berat. Perokok berat ini lah yang sangat tidak baik, karena kadang-kadang mereka tidak melihat situasi bahkan merokok di tempat yang tertutup 
sekalipun padahal banyak orang yang berada di sekitarnya.

"Saya pikir mereka itu kalau lihat perilaku mereka itu memang bisa dikategori ada beberapa ada yang memang perokok berat, ada yang sedang, ada yang ringan. Kalau yang perokok berat kadang-kadang dia tidak mau lihat situasi dia kadang-kadang menyebalkan gitu apalagi tempat tertutup iya kan udah tertutup dia tidak mau lihat kanan kiri langsung seperti nggak ada orang lagi sehingga yang menjadi efek apa ya merokok dianya itu di sekitarnya itu." KI. 2.

Selanjutnya,sikap para informan terhadap fatwa Majelis Tarjih dan Tajdid Muhammadiyah No. 6/SM/MTT/III/2010 tentang hukum merokok. Sebagian besar para informan, baik perokok, tidak perokok, dan mantan perokok, memberikan tanggapan yang positif terkait adanya Fatwa hukum merokok tersebut. Salah satu informan perokok mengatakan bahwa fatwa tersebut memang untuk warga Muhammadiyah dan hal itu harus ditaati sehingga dengan adanya fatwa itu, ia berupaya untuk berhenti merokok. Namun pendapat lain yang cukup menarik bahwa informan ini memberikan tanggapan yang positif terhadap keluarnya fatwa akan tetapi hal tersebut mungkin dikarenakan ia bekerja di Muhammadiyah. Ia juga mengatakan bahwa sebagai seorang perokok, kadang-kadang ia mengikuti area yang dibatasi untuk merokok dan berusaha untuk mengurangi merokok. Pernyataannya sebagai berikut:

"Ya kalo saya si nanggapnya ya positif aja si emang ya mungkin karena saya mungkin kerja disini mungkin ya bukan karena orang luar kali. Tanggapan saya positif aja emang. Dengan adanya fatwa itu positif gitu ya tanggapannya." M.5

"Kalo misalnya ada yang nanggapinnya silahkan nggak juga gitu kan saya. Cuman ya saya kalo ada fatwa ini ini aja kadangkadang apa mengikuti area area yang dibatas gitu. Mengikuti area yang dibatas area bebas rokok dan saya juga sendiri berusaha. (berusaha mengurangi)." M.5

Tanggapan yang sama juga diberikan oleh hampir seluruh informan yang tidak merokok. Mereka mengatakan bahwa fatwa adalah merupakan sebuah usaha untuk memberikan penyadaran kepada warga Muhammadiyah agar dapat hidup lebih sehat dan dapat mengamalkan ajaran agamanya. Hal yang sama juga dikemukakan oleh mantan perokok bahwa semua informan mantan perokok memberikan sikap terkait fatwa hukum merokok adalah haram dengan sikap yang positif. Salah satu informan mengatakan bahwa pemberi fatwa merupakan majelis yang sesuai bidangnya yaitu memberikan fatwa terkait keagamaan termasuk fatwa terkait kesehatan. Sebagai dasar pengharaman rokok adalah karena rokok dapat merusak kesehatan. Jawaban informan tersebut seperti berikut ini:

'Tarjih ini kan membidangi fatwa terkait keagamaan, terkait kehidupan beragama termasuk kesehatan. Kenapa mungkin rokok dianggap barang haram, yaitu dasarnya sudah ada. Karena itu merusak kesehatan. Itu benar, artinya menurut saya." MP.1

Pandangan yang sama juga disampaikan oleh key informan sebagai tanggapan terhadap keluarnya fatwa hukum merokok. Beliau mengatakan bahwa fatwa secara agama sudah tepat karena fatwa ditinjau dari beberapa segi seperti kesehatan, ekonomi, dan mudaratnya. Dikarenakan nilai mudarat merokok lebih besar dari manfaatnya, maka Majelis Tarjih mengeluarkan fatwa haram merokok setelah melalui proses yang panjang. Menurut key informan lainnya, meskipun Majelis Tarjih dan Tajdid Muhammadiyah telah mengeluarkan fatwa hukum merokok, namun kedudukan fatwa sebenarnya tidak mengikat. Beliau mengatakan bahwa fatwa dari sisi hukum Islam tidak mengikat mutlak akan tetapi secara moral di institusi, pelanggar fatwa akan ada rasa malu. Pernyataaan yang dimaksud sebagai berikut:

"Fatwa secara umum dari sisi hukum Islam, tidak mengikat mutlak tetapi secara moral, biasanya yang melanggar fatwa ada rasa malu, beda dengan hasil putusan. Putusan tarjih itu mengikat secara keseluruhan, kalau fatwa itu tidak mengikat secara mutlak tapi mengikat secara moral." KI.3

\section{Norma Subjektif terhadap Fatwa}

Hampir seluruh informan yang merokok menerapkan perilaku atas pendapat dari saran yang diberikan keluarga hanya dengan mengurangi merokok. Salah satu informan mengatakan bahwa dirinya saat ini bisa mengurangi merokoknya sudah lumayan banyak.Sebagian besar informan mengurangi merokok karena masih kecanduan dan sebagian yang lain mengurangi merokok dengan alasan kesehatan serta ingin taat organisasi. Salah satu informan yang menjadikan alasan kesehatan dan 
ingin taat organisasi mengatakan bahwa merokok sebetulnya berdampak tidak baik untuk kesehatan dan seharusnya ketika telah dikeluarkan fatwa, maka suatu keharusan untuk mentaati. Sedangkan penerapan informan dari pendapat yang disarankan oleh pimpinan, hampir semua informan perokok menerapkan pendapatnya dengan mengurangi merokok dan lainnya masih tetap merokok. Salah satu informan mengatakan bahwa sempat terfikir untuk berhenti merokok, akan tetapi ketika bertemu teman lama maka akan merokok lagi.

"Ya tadi saya bilang kadang-kadang kalau kayak gini gitu punya pemikiran sontak ya maunya si kayak gitu pingin berhenti tapi waktu udah berlalu ma ketemu lagi sama kawan lama haha ngerokok lagi. “ M.5

Bagi informan yang tidak merokok, mereka menerapkan perilaku atas pendapat dari saran yang diberikan keluarga dengan tetap tidak merokok. Hal tersebut dilakukan karena untuk kebaikan. Ia mengatakan bersyukur bahwa masih ada yang peduli untuk kebaikannya dan akan menyampaikan saran-saran tersebut ke temanteman yang lainnya. Sedangkan penerapan dari pendapat yang disarankan oleh pimpinan, informan menerapkan pendapatnya dengan tetap tidak merokok. Hal tersebut dilakukan karena sudah ada fatwa dan alasan kesehatan. Salah satu informan mengatakan bahwa pada saat telah dikeluarkannya fatwa maka warga Muhammadiyah harus mentaatinya dan hal tersebut juga berguna bagi kesehatannya. Pernyataannya seperti berikut ini:

"Dan kalau dengan dikeluarkan fatwa ini... apa... eee... kalau yang bagi kader perserikatan warga Muhammadiyah yang punya apa... organisasi. Ketika dikeluarkan fatwa itu adalah sami'na wa atho'na itu apa kalau ditarik ke persoalan kesehatan juga jumlah apa... ee... ini lebih kepada apa... menurunkan eee... apa... angka apa... angka perokok dan ini... penyakit yang disebabkan oleh rokok, khususnya di lingkungan perserikatan warga Muhammadiyah itu. saya lihat itu” TM.2

Demikian juga penerapan dari pendapat yang disarankan oleh teman, seluruh informan yang tidak merokok menerapkan pendapatnya dengan tetap tidak merokok. Hal tersebut dilakukan dengan alasan konsisten dan tidak suka merokok. Salah satu informan mengatakan bahwa ia tetap tidak merokok karena memang tidak suka kepada rokok karena bau asapnya.
Selanjutnya dari informan mantan perokok, menginformasikan bahwa mereka menerapkan perilaku atas pendapat dari saran yang diberikan dengan tidak merokok lagi. Hal demikian dilakukan dengan alasan sudah dapat menghilangkan ketergantungan.

"He em. Karena kan rokok itu kan bikin ketergantungan. Kalau berhenti langsung berhenti mungkin agak sulit, tapi kalau saya berhenti itu, dua bulan baru bisa berhenti banget." MP. 2

\section{Kontrol Perilaku}

Kesehatan dan agama menjadi kontrol perilaku merokok secara internal oleh mereka yang merokok. Salah satu informan mengatakan kesehatan sebagai kontrol perilaku internal. Ia menyadari akan dampak negatif yang disebabkan oleh merokok. Agama juga menjadi kontrol perilaku internal perokok dengan alasan merokok adalah tidak bermanfaat.Sementara bagi informan yang tidak merokok, agama, kesehatan, manfaat, kepedulian, dan konsisten menjadi kontrol perilaku tidak merokok secara internal. Banyak hal yang menjadi kontrol perilaku internal pada diri seorang yang tidak merokok seperti yang telah disebutkan diatas. Salah satu informan mengatakan bahwa ketaatan beragama, kepedulian sosial, dan kepedulian lingkungan menjadi kontrol perilaku internalnya untuk tidak merokok. Pernyataan yang disampaikan seperti berikut ini:

"Satu ya memang kita ini kan ya annadhofatu minal iimaan. Berangkatnya dari situ. Ya gitu kan beriman sama Allah. Annadhofatu minal iimaan, kemudian kedua ketaatan kita sama agama kita. Ketaatan agama, ketaatan sama agama juga kita peduli sosial. Peduli lingkungan gitu kan. Eh apa lagi e sayanglah mubadzir," TM.1

Sedangkan oleh mantan perokok, kesehatan, niat, dan rasa peduli menjadi kontrol perilaku tidak merokok secara internal. Salah satu informan yang mengatakan kesehatan sebagai kontrol perilaku internal menyatakan bahwa dahulu pada saat masih merokok, Ia sering sakit. Namun pada saat berhenti merokok, Ia jarang sakit. Informan lain mengatakan bahwa niat menjadi pengontrol perilaku merokoknya secara internal, yaitu niat untuk menjadi lebih sehat dan tertib.

"Ya terutama sih niat sih untuk merubah diri aja, agar lebih, lebih sehat dari sudut segi kesehatannya dan juga lebih tertib dibanding saya dulu." MP.2 
Selanjutnya mengenai kontrol perilaku dari sisi eksternal informan, diperoleh informasi bahwa hampir semua informan perokok menjadikan keluarga menjadi kontrol perilaku merokok secara eksternal dan sebagian yang lainnya karena lingkungan, fatwa, dan penghasilan. Salah satu pernyataan informan bahwa Ia tidak setuju jika ada seseorang yang sedang merokok dengan menggendong anaknya. Sehingga dapat dikatakan bahwa anak menjadi kontrol perilaku informan ini. Informan lainnya menyatakan bahwa anak, istri, dan lingkungan juga sebagai kontrol perilaku merokoknya.

"Sepertinya apa ya. Tadi selain diri saya sendiri gitu yah. Diri sendiri, lingkungan juga. Anak. Istri juga." M.1

Sementara bagi sebagian besar informan yang tidak merokok, lingkungan menjadi kontrol perilaku merokok secara eksternal dan sebagian yang lainnya karena keluarga, fatwa, dan teman. Salah satu informan mengatakan bahwa lingkungan menjadi kontrol perilaku eksternal terlebih di Muhammadiyah telah ada fatwa hukum merokok. Pernyataan tersebut seperti berikut:

"Kalau dari lingkungan kantor kalau saya lebih ke... selain faktor internal eksternal tadi, kalau kantor lebih... apalagi kalau udah ada fatwa tadi, kalau kita sebagai kader itu udah paling final. Ngga ada ceritanya kita merokok lagi." TM.2

\section{“ya dari lingkungan juga” TM.3}

Sedangkan bagi informan mantan perokok, lingkungan, aturan, penghasilan, teman, dan keluarga menjadi Kontrol Perilaku Eksternal untuk tidak merokok. Salah satu yang disampaikan informan bahwa lingkungan Muhammadiyah sudah tidak boleh merokok sehingga menjadi kontrol perilaku eksternal terlebih adanya fatwa hukum merokok. Pernyataannya sebagai berikut:

"Ya kalau di Muhammadiyah memang nggak boleh kan. Itu kan ada tulisan kawasan dilarang merokok. Gede banget". MP.1

"Salah satunya juga itu dari keluarnya fatwa itu menjadikan kontrol perilaku juga." MP.2

Sementara menurut key informan, salah satu upaya kontrol perilaku pimpinan terhadap perilaku merokok pegawai Pusat Dakwah Muhammadiyah yaitu dengan upaya seruan dan peringatan. Salah satu key informan menyampaikan bahwa ada seruan dan teguran langsung oleh pimpinan di Muhammadiyah. Diantaranya juga telah membuat spanduk dan dari MPKU membuat stiker tentang bahaya tembakau. Berdasarkan hasil observasi, didapatkan bahwa tidak adanya sistem pengawasan perilaku merokok di lingkungan Pusat Dakwah Muhammadiyah yang dibentuk seperti adanya satuan tugas (Satgas) anti rokok yang salah satu fungsinya melakukan pengawasan dan kontrol di area-area tertentu.

\section{Niat}

Berdasarkan temuan penelitian, bahwa sebagian informan yang merokok mempunyai niat untuk berhenti merokok setelah dikeluarkan fatwa sebagian yang lain belum bisa berhenti merokok, hanya mengurangi merokok, dan ada yang masih mempertimbangkan. Salah satu informan mengatakan bahwabisa berhenti merokok merupakan sebuah cita-cita. Sebagian yang lain juga mengatakan bahwa niat untuk berhenti merokok itu ada, akan tetapi masih dipertimbangkan.

"Gimana ya kalau untuk niat berhenti si memang ada tapi masih pertimbangan masih ngerokok-ngerokok juga gitu takut janji saya ingkar-ingkar terus.” M.5

Informan yang mengatakan mempunyai niat berhenti beralasan bahwa Ia adalah warga Muhammadiyah yang seharusnya mengikuti fatwa yang sudah diterbitkan. Salah satu informan mengatakan bahwa fatwa tidak berpengaruh terhadap perilaku merokoknya karena perilaku merokok memerlukan suatu kesadaran.

"Dengan adanya fatwa nggak ada pengaruhnya buat saya. Ya karena ini kan soal kesadaran" M.2

Sedangkan bagi informan yang tidak merokok, seluruh informan tersebut mempunyai niat untuk komitmen tidak merokok setelah dikeluarkan fatwa. Salah satu informan mengatakan bahwa dirinya lebih tegas lagi untuk konsisten tidak merokok, mendoakan orang supaya tidak merokok, dan saling mengingatkan untuk tidak merokok. Seluruh informan yang tidak merokok mempunyai niat untuk komitmen tidak merokok setelah dikeluarkan fatwa dengan alasan yang bervariasi. Diantaranya adalah karena haram, kesehatan, dan bertahan. Salah satu informan mengatakan bahwa alasan untuk komitmen tidak merokok karena rokok adalah 
haram. Ia menambahkan bahwa fatwa tersebut dikeluarkan atas ikhtiar para cendekiawan dan intelektualnya Muhammadiyah yaitu majelis tarjih. Pernyataannya sebagai berikut:

"Betul. Rokok itu haram. Apalagi dari fatwa yang dikeluarkan atas ikhtiar para cendekiawan intelektualnya

Muhammadiyah. Apa tuh.. ini udah niatan. Kita di Muhammadiyah, manhaj yang dikuatkan yaitu manhaj tarjih tadi." TM.2

Demikian juga bagi informan mantan perokok, semua informan mempunyai niat untuk tidak merokok setelah dikeluarkan fatwa. Mereka setuju untuk tidak merokok lagi dengan pernyataan sebagai berikut:

"Setuju Mas" MP.1

"Ketika fatwa itu keluar saya menyatakan diri untuk tidak merokok dari sisi hukum agama, kajian hukum agama sudah bilang haram, maka sebagai orang yang pengen berubah ya seharusnya mengikutin fatwa yang menyatakan haram itu." MP.2

Semua informan mempunyai niat untuk tidak merokok setelah dikeluarkan fatwa karena ada tekad dan fatwa. Seorang informan menyatakan bahwa Ia ingin merubah perilakunya dan mentaati fatwa. Pernyataannya seperti berikut ini:

"Dan juga kembali kepada sisi pribadi saya ingin merubah perilaku dan sikapnya sami'na wa atho'na juga." MP.2

\section{PEMBAHASAN}

Keterbatasan dalam penelitian ini yaitu ditemuinya salah satu divisi di Pusat Dakwah Muhammadiyah yang tidak bersedia diwawancarai, karena penelitian terkait perilaku merokok adalah permasalahan yang sensitif. Namun demikian, setelah peneliti melakukan pendekatan, informan yang bersangkutan bersedia untuk diwawancarai. Keterbatasan lainnya yaitu sulitnya mencari mantan perokok yang sesuai kriteria, yaitu perokok yang telah berhenti merokok setelah tahun 2010 dan telah berhenti 6 bulan sebelum pelaksanaan penelitian.

\section{Peran Fatwa Terhadap Perilaku Merokok}

Peran adalah suatu proses yang dinamis seperti apabila seseorang melaksanakan hak dan kewajibannya sesuai dengan kedudukannya maka ia menjalankan suatu peranan (Soekanto, 2009 dalam Imanuel, 2015). Berkaitan dengan fatwa hukum merokok ini, yang dimaksud dengan peran fatwa adalah adanya suatu hubungan antara fatwa dan perilaku merokok itu sendiri. Sebagian besar para informan, baik perokok, tidak perokok, dan mantan perokok, memberikan tanggapan yang positif terkait adanya Fatwa Majelis Tarjih dan Tajdid Muhammadiyah No. 6/SM/MTT/III/2010 tentang hukum merokok. Sesuai hasil pengamatan bahwa masih terdapat pegawai di kantor Pusat Dakwah Muhammadiyah yang merokok namun merokoknya tidak dilakukan di lingkungan kantor Muhammadiyah, merokoknya dengan cara sembunyi-sembunyi, sebagian juga mereka sudah mulai mengurangi merokok.

Hal di atas sesuai dengan penelitian Casmini (2014) di Kecamatan Kalasan, Sleman yang menyatakan bahwa fatwa haram merokok dari Majelis Tarjih dan Tajdid PP Muhammadiyah memberikan stimulasi warga Muhammadiyah untuk berhenti merokok, akan tetapi secara psikologis, mereka mengalami kesulitan berhenti dikarenakan efek candu dalam rokok. Fatwa haram merokok tersebut memberikan suatu pengaruh untuk lebih memahami bahaya rokok dan mempertimbangkan perilaku merokoknya namun secara psikomotorik tidak berpengaruh signifikan sebagai terapi berhenti merokok. Sama halnya menurut Zahra (2017) dalam penelitian yang dilakukannya terhadap mahasiswa Fakultas Agama Islam, Universitas Muhammadiyah Yogyakarta bahwa Fatwa MUI dan Majelis Tarjih dan Tajdid Muhammadiyah berpengaruh terhadap perilaku konsumsi rokok Mahasiswa Fakultas Agama Islam. Mahasiswa yang mengonsumsi rokok di fakultas tersebut lebih sedikit dibandingkan mahasiswa yang mengonsumsi rokok.

\section{Sikap Terhadap Fatwa}

Newcomb menyatakan bahwa sikap merupakan kesiapan untuk bertindak, bukan merupakan kesediaan untuk bertindak. Sikap belum merupakan suatu tindakan akan tetapi predisposisi tindakan suatu perilaku (Notoatmodjo, 2012). Sikap adalah mengacu pada sejauh mana seseorang memiliki evaluasi atau penilaian yang menguntungkan atau tidak terhadap perilaku yang bersangkutan (Ajzen, 1991).

Hasil penelitian pada informan yang merokok, ditemukan sikap yang negatif terhadap perilaku merokok dan sikap positif terhadap fatwa, akan tetapi sikap tersebut tidak berperan terhadap perilaku merokok. Terdapat jawaban 
yang variatif oleh informan perokok tersebut. Sebagian informan mempunyai niat untuk berhenti merokok setelah dikeluarkan fatwa, sebagian yang lain belum bisa berhenti, hanya mengurangi, dan ada yang masih mempertimbangkan. Hal ini, sebagaimana penelitian sebelumnya yang menyatakan bahwa walaupun sikap para perokok secara umum yang beranggapan perilaku merokoknya tidak baik, namun sikap tersebut tidak berpengaruh terhadap niat dan perilaku untuk berhenti merokok (Asraf, 2015). Penelitian lainnya yang dilakukan kepada mahasiswa UIN Syarif Hidayatullah Jakarta, juga menemukan hal yang sama bahwa secara khusus sikap mempengaruhi intensi perilaku berhenti merokok dan pengaruh ini tidak bersifat signifikan. Berbeda dengan penelitian yang dilakukan di Secondary School di Provinsi Ranong yang menunjukkan adanya hubungan yang signifikan antara sikap terhadap perilaku merokok dengan niat merokok (Anggunia, 2009).

Temuan penelitian pada informan yang tidak merokok, bahwa sikap yang negatif terhadap perilaku merokok dan sikap positif terhadap fatwa tersebut berperan terhadap perilaku tidak merokok. Penelitian ini mendapatkan informasi bahwa seluruh informan yang tidak merokok, mempunyai niat untuk komitmen tidak merokok setelah dikeluarkan fatwa. Demikian juga hasil penelitian yang dilakukan pada mantan perokok. Hasil penelitian pada informan mantan perokok, ditemukan sikap yang negatif terhadap perilaku merokok dan sikap positif terhadap fatwa berperan terhadap niat tidak merokok. Penelitian ini mendapatkan informasi bahwa seluruh informan mantan perokok mempunyai niat untuk tidak merokok setelah dikeluarkan fatwa. Hasil penelitian ini menemukan hal yang sama dengan penelitian sebelumnya bahwa ada hubungan yang signifikan antara sikap terhadap perilaku tidak merokok dengan niat untuk tidak merokok siswa SMP Al hasra (Akhira, 2016). Penelitian lain yang dilakukan pada santri di Kabupaten Kudus juga mengatakan bahwa sikap berpengaruh signifikan terhadap intensi berhenti merokok (Kumalasari, 2014).

Sebagai tindak lanjut dari Fatwa hukum merokok, Muhammadiyah telah berupaya agar fatwa dapat diterapkan oleh warganya diantaranya telah dikeluarkan peraturan turunan fatwa seperti Pernyataan Kesepakatan Bersama tentang penerapan Kawasan Tanpa Rokok, adanya surat edaran nomor 412/I.0/H/2011 perihal penerapan Kawasan Tanpa Rokok (KTR) di Lingkungan Muhammadiyah, dan adanya buku pedoman penerapan KTR di Lingkungan
Muhammadiyah, dan upaya lainnya (Muhammadiyah Tobacco Control Center, 2014).

Fatwa hukum merokok dan peraturan turunannya adalah sebagai reinforcing (faktor penguat) dari sebuah perilaku untuk tidak merokok. Namun demikian hal ini perlu adanya faktor lainnya yang dapat berperan terhadap perilaku merokok. Hansen dalam Sarafino mengatakan bahwa faktor-faktor yang dapat berperan terhadap perilaku merokok antara lain faktor biologis, faktor psikologis, faktor demografis, faktor lingkungan sosial, faktor sosial-kultural, dan faktor sosial politik (Simarmata, 2012).

\section{Norma Subjektif terhadap Fatwa}

Theory of planned behavior
mengindikasikan bahwa norma subjektif memiliki pengaruh pada niat seseorang di dalam mengambil keputusan (Ajzen, 2005). Hasil penelitian pada informan yang merokok, ditemukan bahwa norma subjektif tidak berperan terhadap perilaku merokok. Penelitian ini menemukan bahwa sebagian besar informan menerapkan perilaku atas pendapat dari saran yang diberikan keluarga dengan hanya mengurangi merokok. Ditemukan juga bahwa sebagian besar informan menerapkan perilaku atas pendapat dari saran yang diberikan oleh pimpinan dengan hanya mengurangi merokok. Hal ini berarti bahwa norma subjektif berperan terhadap perilaku merokok namun tidak cukup kuat, karena sebagian besar hanya mengurangi merokoknya dan sebagian masih tetap merokok. Hasil ini didukung oleh penelitian sebelumnya yang menyatakan bahwa meskipun orang-orang dekat di sekitar yang mendukung norma agama sangat diyakini perokok akan menyarankan dan berpendapat fatwa MUI haram merokok baik diikuti, tetapi mereka tetap tidak berniat dan berperilaku untuk berhenti merokok (Asraf, 2015).

Sementara penelitian yang dilakukan kepada informan tidak merokok, ditemukan bahwa norma subjektif berperan terhadap perilaku tidak merokok. Penelitian tersebut menemukan bahwa informan yang tidak merokok menerapkan perilaku atas pendapat dari saran yang diberikan keluarga dan teman dengan tidak merokok. Hal ini sama dengan hasil penelitian sebelumnya bahwa ada hubungan yang signifikan antara norma subjektif dengan niat untuk tidak merokok siswa SMP Al hasra (Akhira, 2016). Penelitian lain juga mengatakan bahwa terdapat hubungan yang signifikan antara norma subjektif dengan niat untuk merokok (Promnuch, 2006). 
Penelitian yang dilakukan di SMP Jatinangor Jawa Barat juga mengatakan bahwa teman sebaya merupakan sumber tekanan bagi individu untuk memutuskan merokok atau tidak merokok (Yee, Sunjaya, \& Karyono, 2015).

Demikian juga penelitian yang dilakukan kepada mantan perokok, ditemukan juga informan mantan perokok menerapkan perilaku atas pendapat dari saran yang diberikan dengan tidak merokok lagi. Hal tersebut didukung penelitian sebelumnya yang menemukan bahwa norma subjektif mempengaruhi intensi perilaku berhenti merokok dan bersifat signifikan (Anggunia, 2009).

\section{Kontol Perilaku}

Theory of planned behavior
mengindikasikan bahwa kontrol perilaku mempunyai pengaruh pada niat seseorang di dalam mengambil keputusan (Ajzen, 2005). Menurut hasil penelitian ini, didapatkan informasi bahwa kontrol perilaku berperan terhadap perilaku seseorang. Secara internal, kesehatan dan agama menjadi kontrol perilaku para perokok. Sementara bagi informan yang tidak merokok, alasan agama, kesehatan, manfaat, kepedulian, dan konsisten menjadi kontrol perilaku tidak merokoknya. Sedangkan bagi mantan perokok, kesehatan, niat dan, rasa peduli menjadi kontrol perilaku tidak merokok.

Demikian juga secara eksternal, didapatkan informasi bahwa sebagian besar keluarga menjadi kontrol perilaku merokok dan sebagian yang lainnya karena lingkungan, fatwa, dan penghasilan.Sementara bagi sebagian besar informan yang tidak merokok, lingkungan menjadi kontrol perilaku dan sebagian yang lainnya karena keluarga, fatwa, dan teman. Sedangkan bagi informan mantan perokok, lingkungan, aturan, penghasilan, teman, dan keluarga menjadi kontrol perilaku untuk tidak merokok.

Berbagai sebab yang menjadi kontrol perilaku seseorang, baik oleh seorang perokok, tidak perokok, dan mantan perokok. Salah satu yang menjadi kontrol perilaku eksternal yang didapat dalam penelitian ini adalah adanya fatwa. Keberadaan fatwa dapat menjadi kontrol perilaku seseorang terkait perilaku merokoknya. Hal ini sesuai dengan penelitian sebelumnya bahwa kontrol perilaku berhubungan signifikan terhadap niat mengikuti fatwa MUI dengan berhenti merokok (Asraf, 2015). Penelitian sebelumnya juga mengatakan bahwa kontrol perilaku memiliki hubungan yang signifikan dengan niat merokok (Promnuch, 2006).
Secara umum, kontrol perilaku secara signifikan berperan terhadap perilaku. Sebagaimana penelitian sebelumnya bahwa Perceived Behavioral Control adalah variabel independen yang memiliki pengaruh paling besar dalam mempengaruhi intensi perilaku berhenti merokok(Anggunia, 2009). Berbeda dengan temuan penelitian lain, bahwa tidak ada hubungan yang signifikan antara persepsi kontrol perilaku tidak merokok dengan niat untuk tidak merokok siswa SMP Al Hasra (Akhira, 2016).

\section{Niat}

Niat merupakan antesenden langsung dari perilaku, artinya semakin kuat niat seseorang untuk melakukan perilaku, semakin besar kemungkinan perilaku tersebut akan dilakukan (Ajzen, 1991). Niat disini dijelaskan untuk memprediksi sebuah perilaku merokok seseorang yang dikaitkan dengan keberadaan fatwa Majelis Tarjih dan Tajdid Pimpinan Pusat Muhammadiyah tentang Hukum Merokok.

Berdasarkan temuan penelitian, bahwa sebagian informan yang merokok mempunyai niat untuk berhenti merokok setelah dikeluarkan fatwa, sebagian yang lain belum bisa berhenti, hanya mengurangi, dan sebagian lagi masih mempertimbangkan. Sebagian informan mempunyai niat untuk berhenti merokok setelah dikeluarkan fatwa karena merasa warga muhammadiyah dan fatwa sebagai sebuah pengingat, sebagian yang lain belum bisa berhenti karena masih menikmati rokok, mengurangi merokok karena mempunyai tekad namun fatwa tidak berpengaruh banyak, dan sebagian lagi masih mempertimbangkan perilaku merokok karena belum bisa meninggalkannya. Artinya niat perokok terhadap perilaku merokok setelah dikeluarkannya fatwa sangat bervariasi. Asraf (2015) menyatakan bahwa sikap tidak berpengaruh terhadap niat mengikuti fatwa MUI dengan berhenti merokok yang berarti meskipun anggapan rokok tidak baik, namun tetap saja tidak berniat berhenti merokok.

Sedangkan bagi informan yang tidak merokok, seluruhnya mempunyai niat untuk komitmen tidak merokok setelah dikeluarkan fatwa. Seluruh informan mempunyai niat untuk komitmen tidak merokok setelah dikeluarkan fatwa dengan alasan yang bervariasi, diantaranya adalah karena haram dan kesehatan. Demikian juga bagi informan mantan perokok, semua informan mempunyai niat untuk tidak merokok setelah dikeluarkan fatwa. Semua informan mempunyai niat untuk tidak merokok setelah dikeluarkan fatwa karena ada tekad dan fatwa. 
Namun demikian sebenarnya fatwa di Muhammadiyah sendiri adalah belum mengikat kedudukan secara organisasi. Dalam Muhammadiyah, terdapat hierarki produk hukum yaitu wacana, fatwa, dan putusan. Putusan adalah produk hukum di Muhammadiyah yang dapat mengikat bagi anggotanya secara organisasi. Sedangkan fatwa lebih mengikat secara moral di organisasi karena memang dikeluarkan oleh majelis yang membidangi keagamaan.

\section{SIMPULAN}

Sebagian besar para informan, baik perokok, tidak perokok, dan mantan perokok, memberikan tanggapan yang positif terkait adanya Fatwa Majelis Tarjih dan Tajdid Muhammadiyah No. 6/SM/MTT/III/2010 tentang hukum merokok. Masih terdapat pegawai di kantor Pusat Dakwah Muhammadiyah yang merokok namun merokoknya tidak dilakukan di lingkungan kantor Muhammadiyah, merokoknya dengan cara sembunyi-sembunyi, sebagian juga mereka sudah mulai mengurangi merokok.

Sikap yang negatif terhadap perilaku merokok dan sikap positif terhadap fatwa tidak berperan terhadap perilaku informan yang merokok. Sedangkan sikap yang negatif terhadap perilaku merokok dan sikap positif terhadap fatwa oleh informan yang tidak merokok, berperan terhadap perilaku tidak merokok. Demikian juga sikap yang negatif terhadap perilaku merokok dan sikap positif terhadap fatwa oleh mantan perokok, berperan terhadap perilaku tidak merokok.

Norma subjektif tidak berperan terhadap perilaku merokok oleh informan perokok karena norma subjektif tidak berperan kepada seseorang untuk berhenti merokok. Norma subjektif berperan terhadap perilaku tidak merokok oleh informan yang tidak merokok karena norma subjektif berperan kepada seseorang untuk tidak merokok. Norma subjektif berperan terhadap perilaku tidak merokok oleh informan mantan perokok karena norma subjektif berperan kepada seseorang untuk tetap tidak merokok.

Kontrol perilaku berperan terhadap perilaku merokok informan, baik perokok, tidak perokok, dan mantan perokok. Hal tersebut karena Informan menyadari bahwa ada yang dapat mengontrol dirinya baik bersifat kontrol perilaku internal maupun eksternal.

Sebagian informan yang merokok mempunyai niat untuk berhenti merokok setelah dikeluarkan fatwa, karena sebagai warga Muhammadiyah seharusnya taat dan menganggap fatwa sebagai sebuah pengingat. Sebagian lainnya yang masih merokok mempunyai alasan yang bervariasi. Sedangkan bagi informan yang tidak merokok, mempunyai niat untuk komitmen tidak merokok setelah dikeluarkan fatwa dengan alasan haram dan alasan kesehatan. Untuk informan mantan perokok, dengan adanya fatwa tentang merokok membuat mereka tambah bertekad untuk tidak merokok. Disarankan kepada Pimpinan Pusat Muhammadiyah agar meningkatkan status fatwa hukum merokok menjadi keputusan Muhammadiyah supaya lebih mengikat secara organisasi dan bagi Pusat Dakwah Muhammadiyah agar dapat menjadi role model implementasi fatwa hukum merokok di lingkungan Muhammadiyah.

\section{DAFTAR PUSTAKA}

Abdullah, A. D. (2013). Studi Komparatif Fatwa Majelis Tarjih Muhammadiyah dan Bahtsul Masail Nahdlatul Ulama tentang Istinbath Hukum Merokok. Tajdida, Volume 11, No 2, Desember 2013.

Ajzen, I. (1991). The Theory of Planned Behavior-Organizational Behavior and Human Decision Processes 50. Jg., S, 179.

Ajzen, I. (2005). Attitudes, Personality and Behavior. New York. USA: Open University Press.

Akhira, R. (2016). Faktor-Faktor yang Mempengaruhi Niat Untuk Tidak Merokok Pada Siswa SMP Islam Al Hasra Depok Tahun 2016. [Skrispi]. Jakarta: Fakultas
Kedokteran dan Ilmu Kesehatan, UIN Syarif Hidayatullah.

Anggunia, K. R. (2009). Peranan Sikap, Norma Subjektif, dan Perceived Behavioral Control (PBC) terhadap Intensi Berhenti Merokok pada Perokok Mahasiswa UIN Syarif Hidayatullah Jakarta. [Skripsi]. Jakarta: Fakultas Psikologi, UIN Syarif Hidayatullah.

Asraf. (2015). Pendekatan Theory of Planned Behavior dalam Mengkaji Perilaku Konsumen Rokok di Simpang Empat Pasca Keluarnya Fatwa Majelis Ulama Indonesia tentang Haram Merokok. E-Jurnal Apresiasi Ekonomi, Volume 3, Nomor 1, 
Januari 2015.

Badan Pusat Statistik. (2010). Penduduk Menurut Wilayah dan Agama yang Dianut Indonesia.

https://sp2010.bps.go.id/index.php/site/tabel ?tid $=321 \&$ wid $=0$

Badan Pusat Statistik. (2015). Profil Statistik Kesehatan 2015. Jakarta: Badan Pusat Statistik.

Casmini. (2014). Dinamika Psikologis untuk Berhenti Merokok Warga Muhammadiyah Kecamatan Kalasan Sleman. Jurnal Psikologika, 19 Nomor 2.

Eriksen, Michael P, et al. (2015). The Tobacco Atlas Fifth Edition. New York: American Cancer Society.

Imanuel, F. C. (2015). Peran Kepala Desa dalam Pembangunan di Desa Budaya Sungai Bawang Kecamatan Muara Badak Kab. Kutai Kartanegara. eJournal Ilmu Pemerintahan, 3 (2): 1182 - 1196.

Kasdi, A. (2014). Maqasyid Syari'ah Perspektif Pemikiran Imam Syatibi dalam Kitab AlMuwafaqat. Yudisia: Jurnal Pemikiran Hukum dan Hukum Islam,

Kementerian Kesehatan. (2011). Pedoman Pengembangan Kawasan Tanpa Rokok. Jakarta.

Kementerian Kesehatan. (2016). Perilaku Merokok Masyarakat Indonesia, Berdasarkan Riskesdas 2007 dan 2013. Jakarta.

Kumalasari, I. (2014). Faktor-Faktor yang Memengaruhi Intensi Berhenti Merokok Pada Santri Putra Di Kabupaten Kudus. Jurnal Penelitian Publikasi.

Lian, Tan Yen., U. D. (2016). The Tobacco Control Atlas: ASEAN Region Third Edition (3rd edition). Bangkok: SEATCA.

Muhammadiyah. (2010). Fatwa Majelis Tarjih dan Tajdid Pimpinan Pusat Muhammadiyah No. 6/SM/MTT/III/2010 tentang hukum merokok, (6), 1-8.

Muhammadiyah Tobacco Control Center. (2014).
Kerangka Kerja Muhammadiyah dalam Pengendalian Produk Tembakau. Yogyakarta.

Notoatmodjo, S. (2012). Promosi Kesehatan dan Perilaku Kesehatan. Jakarta: Rineka Cipta.

PP RI. (2012). Peraturan Pemerintah Republik Indonesia No. 109 Tahun 2012. Jakarta.

Population Reference Bureau. (2017). World Population Data Sheet With A Special Focus On Youth. Washington, DC USA.

Promnuch, P. (2006). Factors Related to Intention to Smoke Cigarettes in Secondary School Students. Mahidol University.

Simarmata, S. (2012). Perilaku Merokok Pada Siswa-Siswi Madrasah Tsanawiyah Negeri Model Kuok Kecamatan Bangkinang Barat Kabupaten Kampar Provinsi Riau Tahun 2012. [Skripsi]. Depok: Fakuultas Kesehatan Masyarakat, Universitas Indonesia.

Syuhadak, F. (2013). Urgensi Fatwa Dalam Perkembangan Hukum Islam. De Jure: Jurnal Hukum dan Syar'iah, 5(2).

Tirtosastro, S., \& Murdiyati, A. S. (2017). Kandungan kimia tembakau dan rokok. Buletin Tanaman Tembakau, Serat \& Minyak Industri, 2(1), 33-44.

Trigiyatno, A. (2011). Fatwa Hukum Merokok dalam Perspektif MUI dan Muhammadiyah. Jurnal penelitian, 8(1). 57-75.

Yee, N. L., Sunjaya, D. K., \& Karyono, R. M. H. (2015). Factors Related to the Intention to Cigarette Smoking among Junior High School Students in Jatinangor Subdistrict, West Java. Althea Medical Journal, 2(3), 314-318.

Zahra, H. (2017). Pengaruh Fatwa MUI dan Majelis Tarjih dan Tajdid Muhammadiyah Tentang Hukum Merokok Terhadap Perilaku Konsumsi Rokok Mahasiswa Fakultas Agama Islam Universitas Muhammadiyah Yogyakarta. [Skripsi]. Yogyakarta: Fakultas Agama Islam, Universitas Muhammadiyah Yogyakarta. 